\title{
Reflection on Organizational Culture from the Perspective of Inner Moral
}

\author{
Bing Yan ${ }^{1}$ Keling Zheng ${ }^{1}$ Bing $\mathrm{Xu}^{2}$ \\ ${ }^{1}$ School of Humanities and Arts, Northeast Petroleum University, Daqing, China, 163318 \\ ${ }^{2}$ China Petroleum $6{ }^{\text {th }}$ Construction Company, Taian, China, 271000
}

\begin{abstract}
Moral was not intrinsic in business, because non-moral business myth had been popular in both theory and practice for a long time. In order to survive in the consumer campaigns, companies tied to combine organizational culture and moral in three stages: spontaneously seeking for social morality, identifying moral norms, and consciously spreading moral norms in organizational culture. But in fact organizational moral might easily become an inner moral and serves for the benefits of organizations, which will do harms to organizations and the public.
\end{abstract}

Keywords: Organizational Culture; Organizational Moral; Inner Moral;

Research interests in organizational culture and ethical climate has burgeoned in the past decade. Ethical work climate has become a component of an organizational culture that influences a member's ability to recognize a problem, make a decision, and determine how to act appropriately (Weber and Gerde, 2011, p. 595). But organizational moral which maybe accord with social morality or not is always ignored by many organizations, while more attention is paid in how to build up an ethical culture on accounting (Douglas and Davidson, 2001, p.101) and so on. And there is an illusion that if the culture of an organization is strong and positive, organizational moral in accord with social morality norms should be established.
Actually, it is a long process for organizational moral, in line with general social moral norms, to form in organizational culture. So it is necessary to inspect the organizational culture from the inner moral.

\section{Integration of Organizational Cul- ture and Social Morality}

As everyone knows, practices of organizational culture were found in some famous Japanese and American companies in the 1980's. Then reflection to their management approaches promoted the maturity of organizational culture. During the formation of organizational culture, it continuously identified social morality and tried to be consistent with it.

\subsection{Seeking for social morality}

Organizational culture in Japan started from disintegrations of tycoon corporations after Word War II. At that time, a lot of CEOs were suspended from the office, and many new managers were promoted from production workshops. They were full of experiences and sympathy to blue-collar workers. It is because of these younger managers using new ideas of freedom and respects to manage companies, that Japanese organizational culture came into being.

These managers brought some special understanding of labor relations, corporate missions and human resources into management reforms. They recognized that the pursuit of profits is not on the top 
priority, but balancing the relative interests, especially increasing the welfare of employees. Therefore, a lot of systems were carried out, such as long-term employment and seniority-order payment. Based on these systems, the companies built up a long-term and stable relationship between them and employees, and increased employees' sense of belonging and cohesiveness. Then, inner welfare systems were put forward. Employees were eligible for housing, health care, recreation facilities, besides general welfare provided by the government, which contributed to establish a relation of wholeness between companies and employees by emotional than economic factors. Moreover, business labor union, not as the opposite of the companies, took part in manage activities that greatly safeguarded order of production and improved the labor relations. All of these were originally called the core of Japanese corporate culture.

From the mention above, we could find that the organizational culture in Japan originated from the reflection on management mode which was based on the hypotheses of instrumental rationality and economic man. If companies view profits as their unique goal and employees as tools to achieve it, it may conflict with democracy and justice values, even lead to a fierce confrontation in labor relationship. So some excellent CEOs put "human" and moral factors into management which becomes the essence of organizational culture. But at this stage, the integration of organizational culture and moral was potential and spontaneous without obvious moral meanings. In other words, at that time, it was only a way to get rid of the barriers of companies' development and there was a long distance to moral recognition of organizational culture.

\subsection{Identification in moral norms}

With the success of Japanese companies in the world, the idea of organizational culture is widely accepted, while the moral meaning of it is not well known. Under the "non- moral enterprise myth", the values of organizational culture focused profits and market without any inspection from social morality. Then business scandals increased rapidly, causing public' anger, and in the end the myth broke. The public sent signals that business should be restricted by moral norms and corporate social responsibility in campaigns of consumers and environmental protection. Many governments also issued decrees and promoted international cooperation to push the companies to take social responsibilities. In some degree, it means that the time when companies unscrupulously pursued profits has gone.

Under enormous pressures of the public, companies had to inspect themselves to respond to demands of social values and began to follow the general social moral norms. When the idea of fairness and justice were widely accepted in organizations, some moral requirements, such as advocating interests of stakeholders, protecting environment, as well as giving back to the society gradually became the main idea of organizational culture.

\subsection{Spreading Moral norms in organ- izational culture}

At this stage, organizational moral is not only accepted, but penetrated into the management activities as an important component in organizational structure and development strategy. A research made by American Business Ethic Center, showed nearly ninety percent of Fortune 500 companies and fifty percent of others have established moral principles. Moreover, a lot of Ethics Committees and ethic offices have been built to know and su- 
pervise moral situation in organizations, which also help employees out of the ethical dilemma by the hotline for moral complaints.

It is obvious that the integration of organizational culture and moral is the result of resultant forces of a good many social factors. During this course, a lot of companies might ignore the social moral norms, oppose passively, and even pretend to be moral ones. And the pursuit of profits always set up obstacles for the spreading and popularity of social moral norms.

\section{Organizational Inner Moral Cli- mate and Its negative effects}

The integration of organizational moral and culture will establish an inner moral climate. Generally speaking, it is a kind of moral opinion shared by all of the organizational members, which always takes organizational or personal interests for granted, and guides members' actions by interests' orientation.

Theoretically, organizational moral should be a necessary component of social moral system which not only passes the social values to organizations, but also coordinates relationship between profits and social responsibilities, and in the end helps companies to be qualified social members. But in fact, the moral values of organizations and the society are not always the same, because of great differences between their interests. It means that is moral to organizations may be not necessarily moral to the society. So, for its own interest, a company may tolerate those actions forbidden by social moral norms. Then organizational moral becomes an inner moral, which will put on a moral coat to organizational immoral activities. After the inner moral comes into being, employees are oriented by moral values of maximizing companies' inter- ests and disregard the general social moral norms in achieving aims of companies.

\subsection{Inner moral screening the social moral norms}

Generally speaking, organizations with the pursuit to wholeness and consistency are apt to be a hotbed for inner moral. Because when a set of values and norms are carried out in companies, they are demanded to obey unconditionally. Those who don't accept or follow inner moral principles will be kick out of organizations. That is not to say there is not moral in this kind of organizations, but their own interests are prior to general morality principles. Then the social morality is easily screened out of the vision of organizations and their members. Not only that, but it also can lead to a conspiracy, that is to say, the immoral action will be concealled or shielded so that employees will turn a deaf ear to it.

\subsection{Inner moral manipulating moral silence}

In daily life, immoral actions always are blamed by everyone with a conscience. But in companies with inner moral, they are ignored and most of members in companies might choose to keep silence instead of speaking out their opinions.

The main reason is that they are lack of consideration on external problem. In that climate, managers and employees are prone to regard the company and themselves as a system for maximum economic efficiency, and try to get the optimal balance of profit and cost. Then when facing any wrongdoings, they will pay the lowest cost to deal with it. That is to say, they may conceal or ignore the immorality to get the maximum profits instead of condemning or bringing it to the public, without thinking of the damage to others. Not only that, but many companies want to take chances not to be discovered be- 
cause of market complexity and information asymmetry.

Then, it is conspired in managers to make employees pay little attention, and not question the wrongdoings, by controlling formal and informal organizational information channels. When there is a different moral opinion, the minority always will yield to the group pressure which causes the whole silence.

\subsection{Inner moral encouraging to shrink responsibilities}

From the viewpoint of free will and responsibility, everyone as a "rational agents", should be free to choose what to do, and take relevant responsibility. But in inner moral culture, when employees doing something immoral or finding others' wrongdoings, they often transfer responsibilities to others by excuses, such as "I was told to do that" or "I did it according to organizational demands".

Originally, the result of shrinking responsibilities comes from the system of administration agent. When works are assigned from top management level by level, subordinates become the agents of them, with agent responsibilities transferred. Once responsibilities for immorality should be taken, neither managers nor employees think they would account for it. Subordinates think what they do is according to the decision made by others, so the one who decides should be responsible for that. However, from superiors' points of view, they shouldn't answer for it, because, if works are done perfectly, there will no immoral consequences, and thus responsibilities should be taken by those who actually do it.

All of these sound reasonable, but in fact they are not. The reason for this situation is that both of them lose sight of the premise: when employees abide by codes of norm and account for his employer, the job shouldn't be immoral. It means that if the task was immoral, they should try to correct and remedy it according to their moral judgment in some degree, rather than commit as a machine. Thus the ones who perform duties shouldn't be exemption from liability, while who makes decisions takes responsibility. Nonetheless, in inner moral climate, members always do as organizations requested, replace personal judgment with organizational judgment without thinking whether the task is moral or not, and shift responsibilities .

\section{Implication}

In most cases, the more powerful organizational culture is, the bigger risk is in inner moral. The inner moral culture is a kind moral misplaced, which comes from the closure of organizational culture to social norms and lack of members' reflection to immorality. So, there are some advices to break up it. First, members' critical and reflective spirit should be highlighted. Top managers should cherish employees' abilities in moral introspection which can help them get rid of thought mode totally obeying demands of superiors, and make organizations be more vigorous, creative and acceptable to the public. Secondly, formal ethical communication channel should be established. Last but not least, supervisions from industry associations should be enhanced to promote companies to cultivate a healthy ethical climate.

\section{References}

[1] James Weber, and Virginia Gerde, "Organizational Role and Environmental Uncertainty as Influences on Ethical Work Climate in Military Units," Journal of Business Ethics, pp. 595-612, 2010.

[2] Patricia Douglas, Ronald Davidson, and Bill Schwartz, "The Effect of Organizational Culture and Ethical Orientation on Accountants' Ethical Judgments," Journal of Business Ethics, pp.101-121, 2001. 